Wolfson Institute of Preventive Medicine Barts and the London School of Medicine and Dentistry, Queen Mary University of London, London, UK

Correspondence to: FJ He f.he@qmul.ac.uk

Cite this as: BMJ2020;369:m2237 http://dx.doi.org/10.1136/bmi.m2237 Published: 10 June 2020

\section{Obesity and covid-19: the role of the food industry}

\section{The viral pandemic makes tackling the obesity pandemic even more urgent}

Monique Tan, Feng J He, Graham A MacGregor

Increasing evidence indicates that obesity is an independent risk factor for severe illness and death from covid-19. ${ }^{1-6}$ In the UK, a population cohort study (428 225 participants; 340 admitted to hospital with confirmed covid-19, 44\% of whom were overweight and $34 \%$ obese $)^{1}$ and the OpenSAFELY study using linked electronic health records (17 425445 participants, 5683 covid-19 deaths ( $29 \%$ overweight, $33 \%$ obese) $)^{2}$ have shown a dose-response relation between excess weight and severity of covid-19. After potential confounders, including age, sex, ethnicity, and social deprivation, were adjusted for, the relative risk of critical illness from covid-19 increased by $44 \%$ for people who were overweight (relative risk 1.44, $95 \%$ confidence interval 1.08 to 1.92 ) and almost doubled for those with obesity $(1.97,1.46$ to 2.65$)$ in the cohort study.

Similarly, in the OpenSAFELY study, after all other risk factors (including comorbidities) were fully adjusted for, the risk of dying from covid-19 increased with obesity severity, from a $27 \%$ higher risk in the first obesity category (body mass index (BMI) 30-34.9; hazard ratio $1.27,1.18$ to 1.36) to more than doubling of the risk in the most obese category (BMI >40; 2.27, 1.99 to 2.58). ${ }^{2}$ Smaller studies from the Asia-Pacific region, Europe, and the US have confirmed these findings. ${ }^{3-6}$

Multiple mechanisms could explain the relation between obesity and covid-19. Angiotensin converting enzyme-2 (ACE-2), the transmembrane enzyme that SARS-CoV-2 uses for cell entry, exists in larger quantities in people with obesity. Whether this is the result of higher ACE-2 expression in the adipocytes of people with obesity or having more adipose tissue in general (and thus a greater number of ACE-2 expressing cells) is not yet clear. ${ }^{7}$ The adipose tissue of people with obesity may therefore be a potential target and viral reservoir for SARS-CoV-2 before it spreads to other organs, as has proved to be the case for other viruses. ${ }^{8}$

Obesity can also alter immune responses, as has been shown with the influenza virus, leading to weakened host defence and a greater chance of a cytokine storm with covid-19. ${ }^{910}$ Finally, obesity diminishes lung function through greater resistance in the airways and more difficulty in expanding the lungs. When patients with obesity need to be admitted to intensive care units it is challenging to improve their oxygen saturation levels and ventilate them. ${ }^{9}$

\section{Unhealthy environment}

The covid-19 outbreak seems to be yet one more health problem exacerbated by the obesity pandemic. In 2016 more than 1.9 billion adults were overweight or obese worldwide, and this number continues to rise rapidly. ${ }^{11}$ The prevalence of overweight and obesity has now reached $65-70 \%$ in the UK and US adult populations. ${ }^{1213}$ Obesity is a major cause of high blood pressure, type 2 diabetes, heart disease, stroke, and cancer and places a great burden on health systems and economies. ${ }^{11}$ In 2014-15 the NHS spent more than $€ 6 \mathrm{bn}$ ( $€ 6.7 \mathrm{bn}$; $\$ 7.6 \mathrm{bn})$ on tackling the direct consequences of obesity. ${ }^{14}$

The obesity pandemic is the result of living in food environments where it is difficult not to overconsume calories. The global food industry produces and extensively promotes cheap, sugar sweetened beverages and ultraprocessed foods high in salt, sugar, and saturated fat that provide only a transient sensation of fullness. Governments have done too little, with one of the few successes being taxes on sugar sweetened beverages-in particular, the industry levy in the UK that has resulted in reformulation to reduce the sugar content. ${ }^{15}$

It is now clear that the food industry shares the blame not only for the obesity pandemic but also for the severity of covid-19 disease and its devastating consequences. During the covid-19 pandemic an increase in food poverty, disruptions to supply chains, and panic buying may have limited access to fresh foods, thus tilting the balance towards a greater consumption of highly processed foods and those with long shelf lives that are usually high in salt, sugar, and saturated fat. Moreover, since the start of the covid-19 pandemic the food industry has launched campaigns and corporate social responsibility initiatives, often with thinly veiled tactics using the outbreak as a marketing opportunity (for example, by offering half a million "smiles" in the form of doughnuts to NHS staff).

Food industries around the world must immediately stop promoting, and governments must force reformulation of, unhealthy foods and drinks. In the UK, incremental targets have already gradually reduced the amount of salt added to foods, resulting in lower salt intake, blood pressure, and cardiovascular mortality. ${ }^{16}$ Reducing salt, sugar, and saturated fat across the board would improve the diet of the entire population and bring even greater benefits for people who are most socially deprived. The toll of morbidity and mortality from covid-19 has made this more apparent and more urgent than ever.

Competing interests: The BM/has judged that there are no disqualifying financial ties to commercial companies. FJH is a member of the Consensus Action on Salt and Health and its international branch, World Action on Salt and Health. GAM is the chair of Blood Pressure UK, the Consensus Action on Salt and Health, and World Action on Salt and Health.

Provenance and peer review: Not commissioned; externally peer reviewed. 
1 Ho FK, Celis-Morales CA, Gray SR, et al. Modifiable and non-modifiable risk factors for COVID-19: results from UK Biobank. medRxiv 2020.04.28.20083295. [Preprint.]

doi: 10.1101/2020.04.28.20083295

2 OpenSAFELY Collaborative. OpenSAFELY: factors associated with COVID-19-related hospital death in the linked electronic health records of 17 million adult NHS patients. medRxiv 2020.05.06.20092999 [Preprint.] doi: 10.1101/2020.05.06.20092999

3 Simonnet A, Chetboun M, Poissy J, etallille Intensive Care COVID-19 and Obesity study group. High prevalence of obesity in severe acute respiratory syndrome coronavirus-2 (SARS-CoV-2) requiring invasive mechanical ventilation.Obesity (Silver Spring) 2020. [Epub ahead of print.] . doi: 10.1002/oby.22831 pmid: 32271993

4 Lighter J, Phillips M, Hochman S, etal. Obesity in patients younger than 60 years is a risk factor for Covid-19 hospital admission. Clin Infect Dis 2020: [Epub ahead of print.] . doi: 10.1093/cid/ciaa415 pmid: 32271368

5 Petrilli CM, Jones SA, Yang J, etal. Factors associated with hospital admission and critical illness among 5279 people with coronavirus disease 2019 in New York City: prospective cohort study. BMJ 2020;369:m1966. doi: 10.1136/bmj.m1966. pmid: 32444366

6 Huang R, Zhu L, Xue L, etal. Clinical findings of patients with coronavirus disease 2019 in Jiangsu province, China: a retrospective, multi-center study. PLoS Negl Trop Dis 2020;14:. . doi: 10.1371/journal.pntd.0008280 pmid: 32384078

7 Kruglikov IL, Scherer PE. The role of adipocytes and adipocyte-like cells in the severity of COVID-19 infections. Obesity (Silver Spring) 2020. [Epub ahead of print.] doi: 10.1002/oby.22856 pmid: 32339391

8 Kassir R. Risk of COVID-19 for patients with obesity. Obes Rev 2020;21:. . doi: 10.1111/obr.13034 pmid: 32281287

9 Sattar N, McInnes IB, McMurray JJV. Obesity a risk factor for severe covid-19 infection: multiple potential mechanisms. Circulation 2020. [Epub ahead of print.] doi: 10.1161/CIRCULATIONAHA.120.047659 pmid: 32320270

10 Green WD, Beck MA. Obesity impairs the adaptive immune response to influenza virus. Ann Am Thorac Soc 2017;14(Suppl 5):S406-9.. doi: 10.1513/AnnalsATS.201706-447AW pmid: 29161078

11 World Health Organization. Obesity and overweight 2020. https://www.who.int/news-room/factsheets/detail/obesity-and-overweight

12 NHS Digital. Health Survey for England 2017. 2018. https://digital.nhs.uk/data-and-information/publications/statistical/health-survey-for-england/2017

13 National Center for Health Statistics. Obesity and overweight 2018.https://www.cdc.gov/nchs/fastats/obesity-overweight.htm

14 Public Health England. Health matters: obesity and the food environment 2017. https://www.gov.uk/government/publications/health-matters-obesity-and-the-food-environment/health-matters-obesity-and-the-food-environment--2

15 Bandy LK, Scarborough P, Harrington RA, Rayner M, Jebb SA. Reductions in sugar sales from soft drinks in the UK from 2015 to 2018. BMC Med 2020;18:20. doi: 10.1186/s12916-019-1477-4 pmid: 31931800

16 He FJ, Pombo-Rodrigues S, Macgregor GA. Salt reduction in England from 2003 to 2011: its relationship to blood pressure, stroke and ischaemic heart disease mortality. BMJ Open 2014;4: . doi: 10.1136/bmjopen-2013-004549 pmid: 24732242

This article is made freely available for use in accordance with BMJ's website terms and conditions for the duration of the covid-19 pandemic or until otherwise determined by BMJ. You may use, download and print the article for any lawful, non-commercial purpose (including text and data mining) provided that all copyright notices and trade marks are retained. 